\title{
Seasonal variations in thermoregulatory patterns enable Morada Nova sheep to adapt to Brazilian semi-arid
}

\section{A variação sazonal de características termorreguladoras permite a adaptação de ovelhas Morada Nova ao ambiente semiárido}

\author{
Wilma Emanuela da Silva ${ }^{1 *}$; Jacinara Hody Gurgel Morais Leite ${ }^{1}$; Wallace Sóstene \\ Tavares da Silva ${ }^{1}$; Renato Diógenes Macedo Paiva ${ }^{1}$; José Ernandes Rufino de \\ Sousa ${ }^{2}$; Débora Andréa Evangelista Façanha ${ }^{2}$
}

\begin{abstract}
The present study aimed evaluate possible modifications of thermoregulatory morphophysiological responses of Morada Nova sheep throughout the year in 4 properties of the nucleus of participatory genetic breeding. In the months of March, June, September and December, respiratory rate (RR), rectal temperatures (RT) and surface (ST) were recorded as well as the environmental variables air temperature (airT), relative humidity $(\mathrm{RH})$ wind (Ws). Calculated the radiant heat load (RHL) and the Black Globe Humidity Index (BGHI). The coat thickness was measured and hair samples were collected and determined hair density, hair length and hair diameter. Blood collection was collected for determination of $\mathrm{T}_{3}$ and total $\mathrm{T}_{4}$ concentrations. In the rainy season, which includes the months of March and June, higher values of RR and RT, probably due to the combination of high RH, associated to RHL, BGHI and airT were recorded, as these hamper loss and heat. All values of RT independent of month and flocks remained within values considered normal for the species. September and December are inserted in the dry season, with a low RH factor that can facilitate heat loss through evaporation. In these months, lower values of RT and RR were observed when compared to the rainy season, lower values of RR were recorded between 40 and 60 mov. $\mathrm{min}^{-1}$. The secretion of thyroid hormones was greater in the environmental conditions considered more comfortable. The homeothermia was maintained by Morada Nova sheep at different times evaluated as indicated by the normal physiological parameters. The rainy season was considered the most stressful for the animals, since they used a more intense set of variables in order to thermoregulate and maintain the homeothermia, which justifies the importance of providing shelters, with the objective of reducing the overheating, even in view of their great adaptive capacity, already demonstrated in previous studies. Changes in the coat characteristics were observed during all the months of the year, assisting for either physical protection or heat dissipation and could therefore be indicated as a thermotolerance phenotypic marker with the potential to be used as selection criteria in breeding programs and conservation of resistant animals to heat.
\end{abstract}

Key words: Adaptive characteristics. Coat characteristics. Phenotypic markers.

\footnotetext{
1 Discentes, Programa de Pós-Graduação em Ciência Animal, Universidade Federal Rural do Semi-Árido, UFERSA, Campus Mossoró, Mossoró, RN, Brasil. E-mail: wilma_manu1@hotmail.com; narinhazootecnista@hotmail.com; wstdsharm@gmail. com; renatodiogenes@gmail.com

2 Profs., UFERSA, Campus Mossoró, Mossoró, RN, Brasil. E-mail: ernandes@ufersa.edu.br; debora_ufersa@hotmail.com

* Author for correspondence
} 


\section{Resumo}

O presente estudo objetivou avaliar possíveis modificações de respostas morfofisiológicas termorreguladoras de ovelhas da raça Morada Nova, ao longo do ano, em 4 propriedades do núcleo de melhoramento genético participativo. Nos meses de Março, Junho, Setembro e Dezembro foram registradas as frequências respiratórias (FR), temperaturas retais (TR) e de superfície (TS) assim como as variáveis ambientais temperatura do ar (Tar), umidade relativa (UR) e velocidade do vento (Vv). Calculada a carga térmica radiante (CTR) e o índice de temperatura de globo e umidade (ITGU). Foi medida a espessura da capa de pelame e amostras de pelo foram coletadas e determinadas a densidade numérica, o comprimento médio e o diâmetro médio. Coleta de sangue foi realizada a para a determinação das concentrações de $\mathrm{T}_{3}$ e $\mathrm{T}_{4}$ total. Na estação chuvosa que compreende os meses de Março e Junho, foram registrados maiores valores de FR e TR, provavelmente pela combinação de alta UR, associada a CTR, ITGU e Tar, pois estas dificultam a perda e calor. Todos os valores de TR independente de mês e rebanho mantiveram-se dentro de valores considerados normais para a espécie. Setembro e dezembro estão inseridos na estação seca, com baixa UR fator esse que pode facilitar as perdas de calor via evaporação. Nestes meses foram observados menores valores de TR e FR se comparados com o período chuvoso, foram registrados menores valores de FR entre 40 a 60 mov.min- ${ }^{-1}$. A secreção dos hormônio tireoidianos foram maiores nas condições ambientais consideradas mais confortáveis. A homeotermia foi mantida pelos ovinos Morada Nova, nas diversas épocas avaliadas conforme indicado pelos parâmetros fisiológicos normais. O período chuvoso foi considerado o mais estressante para os animais, haja visto que utilizaram de forma mais intensa um conjunto de variáveis no intuito de se termorregularem e manter a homeotermia, o que justifica a importância do fornecimento de abrigos, com o objetivo de reduzir o superaquecimento dos animais, mesmo diante da grande capacidade adaptativa dos mesmos, já demonstrada em estudos anteriores. Alterações nas características de pelame foram observadas durante todos os meses do ano, auxiliando tanto na proteção física quanto na dissipação de calor, podendo assim ser indicadas como marcador fenotípico de termotolerância com potencial para ser utilizado como critérios de seleção em programas de melhoramento genético e conservação de animais resistentes ao calor.

Palavras-chave: Características adaptativas. Características de pelame. Marcadores fenotípicos.

\section{Introduction}

There is growing interest in the adaptation of production animals to tropical regions, especially considering abrupt climatic changes and their direct influence on the productivity of the main species of domestic animals, particularly those that are sensitive to high air temperature and solar radiation. Such environmental conditions are often recorded in tropical regions throughout the year, and most often represent a limiting factor on animal performance (HOFFMANN, 2010; RUST; RUST, 2013).

Many mechanisms are used by animals to maintain thermal equilibrium under a stressful environment; these may include immediate responses (elevation of rectal temperature, respiratory rate, skin evaporation) as well as long-term responses that can be expressed as changes in hormone concentrations and alterations in some coat characteristics, which suggest the acclimatization of the animals. The hypothalamus is heat sensitive, which is reflected in a change in the concentration of thyroid hormones (KOLUMAN; DASKIRAN, 2011; MAURYA et al., 2010; VERÍSSIMO et al., 2009). These hormones are directly involved in the regulation of metabolic rate and obligate thermogenesis, playing a decisive role in thermoregulation and homeotermic conditions. Other changes that could occur in animals in a hot environment are related to external coat characteristics (SILVA; STARLING, 2003).

It is important to adopt breeds with heat tolerance to environments with high air temperatures; animals with a better genotype $\mathrm{x}$ environment interaction will tend to present better productive performance, caused by the better utilization of native vegetation, resistance to parasites, less impact on physiological 
aspects, as well as being economically more viable. According to Sejian et al. (2010), animals raised in semi-arid regions are subject to more than one stressor simultaneously, although thermal stress is the most severe stressor. Therefore, the maintenance of body temperature within the physiological limits is necessary for the animals to remain healthy in order to survive and maintain their productivity (MARAI et al., 2007).

Morada Nova sheep are important genetic resources that are locally adapted to the northeastern region of Brazil. This attribute is related to some physical characteristics, such as: a pigmented epidermis covered by hair, which helps to protect against sunlight; and a high capacity for survival, production and reproduction against the severe climatic and nutritional conditions of the Brazilian semi-arid regions. However, there is little information on the critical times of year, in terms of the ability of these animals to thermoregulate, as well as technical measures to be adopted, associated with nutrition, reproduction and sanity. Such information is necessary since the evaluation and selection criteria used by breeders are based only on characteristics of racial pattern (LEITE et al., 2018), with most of them disregarding characteristics that are related to adaptability.

Several researchers have conducted studies on the adaptation of animals to the environment, but few are concerned with conducting these studies within the production units, considering the natural environmental conditions in which the animals are raised. It is consensual that Morada Nova animals are able to withstand high caloric, nutritional and sanitary stress at any time of the year (COSTA et al., 2015; FERREIRA et al., 2017, 2018; LEITE et al., 2017; SILVA et al., 2017).

The present work aimed to evaluate the possible changes in the physiological parameters and coat characteristics of Morada Nova sheep exposed to natural changes in the environment throughout the year in a semi-arid region. It is expected that this study will provide subsidies to indicate a phenotypic marker of thermotolerance, so that it could be included as a selection criterion in improvement breeding programs. It will also allow for the generation of information that will contribute to the identification of the most stressful periods of the year, which will be necessary for the adoption of measures to protect animals against excessive heat loads.

\section{Materials and Methods}

\section{Animals and experimental design}

All procedures used in this study were in accordance with ethical standards and approved by the Animal Ethics Committee of the UFERSA (Protocol 23091003895 / 2014-71). The work was conducted on four properties participating in the Improvement Nucleus of Morada Nova breed, in which a semi-intensive production system is adopted (Table 1). All properties were located in Morada Nova city, Ceará, Brazil $\left(6^{\circ} 05^{\prime}\right.$ 'South latitude, $39^{\circ} 23^{\prime}$ 'West longitude), a semi-arid region of Brazil belonging to the Caatinga Biome, a complex ecosystem with high animal and vegetal biodiversity, with predominant xerophytic and hyperxerophytic plants.

Table 1. Geographical position of each flock evaluated.

\begin{tabular}{lcccccc}
\hline Localization & Flock & Latitude & Longitude & Height $(\mathrm{m})$ & Number of sheep & Data number \\
\hline Morada Nova & 1 & $-5^{\circ} 44^{\prime} 10^{\prime \prime}$ & $39^{\circ} 97^{\prime} 20^{\prime \prime}$ & 66 & 40 & 160 \\
Morada Nova & 2 & $-5^{\circ} 04^{\prime} 17^{\prime \prime}$ & $38^{\circ} 23^{\prime} 40^{\prime \prime}$ & 115 & 36 & 144 \\
Morada Nova & 3 & $-5^{\circ} 09^{\prime} 02^{\prime \prime}$ & $38^{\circ} 18^{\prime} 29^{\prime \prime}$ & 39 & 40 & 160 \\
Morada Nova & 4 & $-7^{\circ} 94^{\prime} 05^{\prime \prime}$ & $37^{\circ} 97^{\prime} 00^{\prime \prime}$ & 155 & 26 & 104 \\
\hline
\end{tabular}


The reproductive-aged ewes were selected from each herd, previously submitted to a physical examination for confirmation that they were free of any deformity that indicated their discard. The same animals were evaluated, in each herd, throughout the experimental period.

The data were collected every three months (March, June, September and December), distributed during the rainy (March and June) and dry (September and December) seasons. Data collection always started at 09h00.

\section{Characterization of the four flocks}

Data were collected from the red variety of Morada Nova sheep from four different commercial herds belonging to the nucleus of conservation of the breed and registered by the Association of Sheep Breeders (ARCO), with controlled reproductive management; this was done during the year with monitoring through zootechnical bookkeeping. The properties were characterized as follows:

Flock 1: The property was characterized by the production of dairy cows (30 to 60 cattle) as the main economic activity, and sheep (150 animals) as a secondary activity. The same 40 ewes were availed during the experimental period. The animals spent the day grazing in the Caatinga vegetation; they received mineral salt supplementation at night when they returned to the installations. The property had little vegetation cover or trees. During the dry period, the animals received concentrate and silage or hay. The water resources were from the Banabuiú River and artesian sources. The mean live weight of the animals was $33.85 \mathrm{~kg}$.

Flock 2: The farm had about 150 sheep, 36 of which were used in the experiment. The animals remained in the native vegetation of Caatinga during the day, even during the dry season, when forage was scarce. The property was composed of masonry installations; however, they had a few covered areas. The mean live weight of the animals was $30.46 \mathrm{~kg}$ during the experimental period.

Flock 3: Sheep breeding was not the main economic activity of the farm. The property was inserted in an irrigated perimeter; it had a river to supply water. The farm had approximately 200 animals, however, 40 ewes were used for the experiment. The animals were managed extensively. The mean weight was $31.83 \mathrm{~kg}$ during the experimental period.

Flock 4: The farm had a small herd with a total of 40 animals; only 26 were used for the experiment. The mean weight of the animals was $30.68 \mathrm{~kg}$ during the experimental period. The animals spent the day on native vegetation and only returned to the installations at night.

\section{Meteorological traits}

The thermal environment in which the animals grazed was monitored during the experimental period, including registrations of: air temperature (AirT) and relative humidity $(\mathrm{RH})$ recorded by a digital thermocouple; wind speed (Ws) measured using a portable anemometer (Model AVM-07); and black globe temperature exposed to the sun. With these data, the environmental comfort indexes were estimated, such as the Black Globe and Humidity Index (BGHI) and radiant heat load (RHL), according to Silva (2008).

$\mathrm{BGHI}=\mathrm{Tbg}+0.36+41.5 \mathrm{Tpd}$

Where:

$\mathrm{Tbg}=$ Black Globe Temperature in the sun, ${ }^{\circ} \mathrm{C}$

Tpo $=$ Dew point Temperature, ${ }^{\circ} \mathrm{C}$

$41.5=$ Constante

$\mathrm{RHL}=1.053 \mathrm{hc}(\mathrm{Tg}-\mathrm{Ta})+\boldsymbol{\delta} \mathrm{Tg}^{4}, \mathrm{w} \cdot \mathrm{m}^{-2}$

Where: 
$\mathrm{Hc}=$ coefficient of convection of the black globe, w.m $\mathrm{m}^{-2}$

$\mathrm{Tg}=$ Black Globe Temperature in the sun, ${ }^{\circ} \mathrm{C}$

$\mathrm{Ta}=$ air Temperature, ${ }^{\circ} \mathrm{K}$

$\boldsymbol{\delta}=$ constante de Stephan-Boltzman $(5.6697 \mathrm{x}$ $\left.10^{-8} \mathrm{~W} \cdot \mathrm{m}^{-2} \cdot \mathrm{K}^{-4}\right)$

Environmental data were collected at the same moment as the physiological characteristics were measured.

\section{Physiological traits}

The physiological responses that were assessed included: rectal temperature $\left(\mathrm{RT},{ }^{\circ} \mathrm{C}\right)$, which was measured using a digital thermometer (OMRON FLEX TEMP digital thermometer, China); and respiratory rate $\left(\mathrm{RR}\right.$, breaths. $\left.\mathrm{min}^{-1}\right)$, recorded by counting the number of flank movements per 1 minute. Surface temperature (ST) was registered with an infrared thermometer (Model Dt 8550), obtaining the average temperature of the animal over three different regions of the body (neck, flank and croup). Hormonal serum concentrations were determined using commercial kits for triiodothyronine $\left(\mathrm{T}_{3}\right)$ and thyroxine $\left(\mathrm{T}_{4}\right)$ concentrations in an automatic ELISA device (Elysis Uno ${ }^{\circledR}$, Human ${ }^{\circledR}$ ).

\section{Hair characteristics}

The evaluated hair traits included coat thickness (CT, mm) determined in situ in the middle of the thorax of each animal, about $20 \mathrm{~cm}$ below the dorsal line, with a thin metal rule. The hair samples were taken from the same region where CT was measured, using pliers (SILVA, 2008); these samples were stored in plastic envelopes and taken to the Bioclimatology and Animal Welfare laboratory (UFERSA). Hair length (HL, mm), hair diameter $(\mathrm{HD}, \mu \mathrm{m})$ and hair density $(\mathrm{NH})$ were recorded in the laboratory. HL was the average length of the
10 longest hairs in the sample, according to Udo's method (1978). HD was recorded using a digital micrometer (MITUTOYO MODEL, with a scale of 0-25 $\mu \mathrm{m}$ ), measured from the same hair used for HL. $\mathrm{NH}$ was obtained by counting the number of hairs removed from $0.1399 \mathrm{~cm}^{2}$ using pliers, according to Lee (1953), then converted into $1 \mathrm{~cm}^{2}$ (MAIA et al., 2003).

\section{Statistical analysis}

The statistical tests included a multivariate analysis and correlations. Principal component analysis allows for an assessment of the overall variance; on the other hand, discriminant analysis describes the variation between herds and identifies variables with greater discriminatory power. The data were analyzed using the SPSS program. Analyses of variance were performed using the PROC MIXED procedure of SAS, with the animal as a repeated measure. The statistical model included the effect of herd, the month of data collection, the interaction between the factors, plus the weight of the animals as a coefficient of quadratic regression.

$$
y_{i j k}=\mu+M_{i}+H_{j}+M(H)_{i j}+b P^{2} \varepsilon_{i j k}
$$

\section{Results and Discussion}

The principal component analysis (PCA) showed that the first axis was related to the environmental variables, such as air temperature (AirT), radiant heat load (RHL), the Black Globe and Humidity Index (BGHI), and relative humidity $(\mathrm{RH})$ for the variables of coat thickness (CT) and hair density. $\mathrm{cm}^{-2}\left(\mathrm{NH} . \mathrm{cm}^{-2}\right)$ in the animals (Figure 1a). There was an inverse relationship between airT, RHL, BGHI, and $\mathrm{RH}$, characterizing the environment as hot and dry. This same relationship was observed by Leite et al. (2017), who also studied the same variables and the same breed in a semi-arid environment. 
Figure 1. Principal component analysis for the environmental, physiological, morphological and thyroid hormone variables, measures were: air $\mathrm{T}=$ air temperatura, $\mathrm{RH}=$ relative humidity, $\mathrm{RHL}=$ radiante heat load, $\mathrm{BGHI}$ - black globe humidity index, $\mathrm{Ws}=$ Wind speed, $\mathrm{ST}=$ surface temperature, $\mathrm{RT}=$ rectal temperature, $\mathrm{RR}=$ respiratory rate, $\mathrm{NH} . \mathrm{cm}^{-2}=$ hair density, $\mathrm{HD}=$ hair diameter, $\mathrm{CT}=$ coat tickness, $\mathrm{HL}=$ hair length, $\mathrm{T}_{3}=$ triiodothyronine e $\mathrm{T}_{4}=$ thyroxine.

a

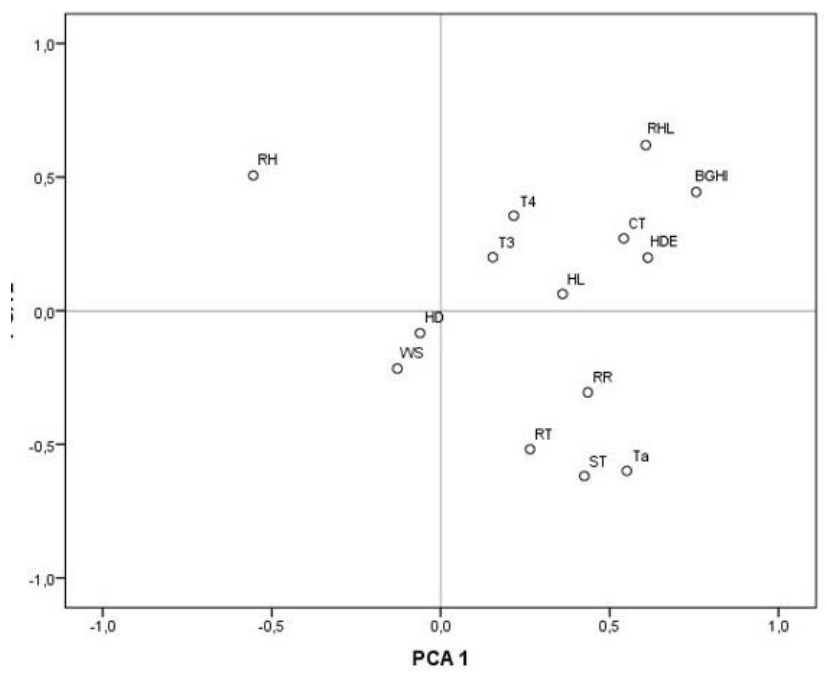

The second axis of the PCA was related to the environmental variables (airT, RHL and RH) and the animal variables of surface temperature (ST) and rectal temperature (RT). airT showed an inverse relationship to $\mathrm{RHL}$ and $\mathrm{RH}$, indicating that in the wettest season, the ambient temperature was lower, probably due to less radiation reaching the surface, which can be attributed to greater cloudiness; this may also be associated with a lower RHL when the airT increases. ST and RT showed an inverse and negative correlation with RHL; there is a direct relationship between ST and RT with RH, possibly because a higher $\mathrm{RH}$ is associated with higher cloudiness and a lower fraction of radiation reaching the surface of the animal (Figure 1a).

Figure $1 \mathrm{~b}$ shows the effect of the variables within the studied months. In March, the animals tended to present higher values of RR, RT and ST. According to McDonald (1980), well-adapted animals respond quickly to environmental changes, providing the required physiological adjustments. June, during the rainy season, was the month with the highest $\mathrm{RH}$, and September had the highest values of RHL, BGHI and Ws. In December, the behavior of

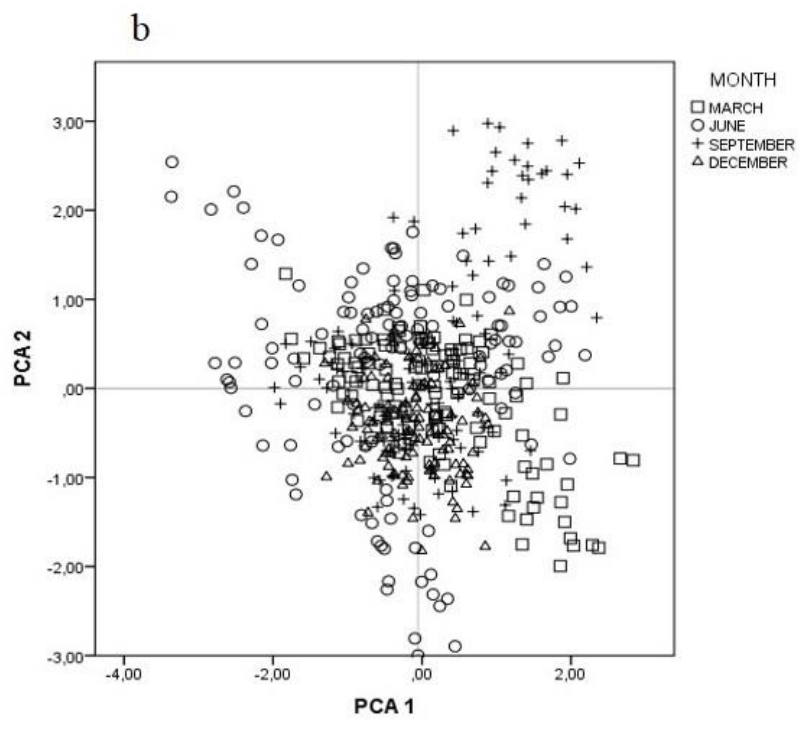

variables remained at the center of the analysis, thus demonstrating a balance in the values of the studied variables.

The combination of high values of RHL, BGHI, $\mathrm{RH}$, and airT in March allowed the animals to intensify their thermoregulation mechanisms, more intensely triggering the variables ST, RR and RT. The higher the RHL, the greater the solar rays are absorped by the epidermis and consequently, there is increase of ST, triggering a more intensive RR in order to maintain internal temperature, which was possibly not enough to keep the RT constant (Table 2). Panagakis (2011) emphasizes the importance of monitoring RT and RR in animals exposed to heat stress, since they are considered good indicators of thermal discomfort. Some authors have set classifications for these characteristics for ovine species, in which a RR up to 39.7 breaths. $\mathrm{min}^{-1}$ is considered normal (ROGER, 2008), 40 to 60 breaths. min $^{-1}$ is classified as low stress, 60 to 80 breaths. min $^{-1}$ as moderate stress, 80 to 120 breaths. min $^{-1}$ is considered high stress and above 120 breaths. min $^{-1}$ is classified as severe stress (SILANIKOVE, 2000). However, McManus et al. 
(2008) note that an increased respiratory rate may a mechanism for controlling homeothermia under the imposed environmental conditions, since sheep are known for their ability to lose heat through respiration (COLLIER; GEBREMEDHIN, 2015) and their rate of sweating in hot environments (SILVA et al., 2017).

Table 2. Means of environmental, thermoregulatory and hormonal variables of Morada Nova ewes according to the month of collection.

\begin{tabular}{|c|c|c|c|c|}
\hline & March & June & September & December \\
\hline airT $\left({ }^{\circ} \mathrm{C}\right)$ & $35.54^{\mathrm{b}}$ & $33.37^{\mathrm{c}}$ & $35.58^{b}$ & $36.71^{\mathrm{a}}$ \\
\hline RH (\%) & $40.53^{b}$ & $51.13^{\mathrm{a}}$ & $38.26^{\mathrm{c}}$ & $39.61^{\mathrm{c}}$ \\
\hline $\operatorname{RHL}\left(\mathrm{w} \cdot \mathrm{m}^{-2}\right)$ & $666.18^{a}$ & $638.25^{\mathrm{b}}$ & $671.89^{\mathrm{a}}$ & $549.93^{c}$ \\
\hline BGHI & $91.00^{\mathrm{a}}$ & $88.37^{\mathrm{b}}$ & $91.20^{\mathrm{a}}$ & $85.02^{\mathrm{c}}$ \\
\hline Ws $\left(m \cdot s^{-1}\right)$ & $1.27^{\mathrm{b}}$ & $0.95^{\mathrm{c}}$ & $1.48^{\mathrm{a}}$ & $0.97^{\mathrm{c}}$ \\
\hline Pp month (mm) & 89.8 & 137 & 0 & 19.1 \\
\hline $\mathrm{ST}\left({ }^{\circ} \mathrm{C}\right)$ & $37.04^{\mathrm{a}}$ & $35.99^{\mathrm{bc}}$ & $35.45^{\mathrm{c}}$ & $36.30^{\mathrm{b}}$ \\
\hline $\mathrm{RT}\left({ }^{\circ} \mathrm{C}\right)$ & $39.02^{\mathrm{a}}$ & $38.98^{\mathrm{a}}$ & $38.73^{b}$ & $38.81^{\mathrm{b}}$ \\
\hline RR (breath.min ${ }^{-1}$ ) & $64.91^{\mathrm{a}}$ & $54.68^{\mathrm{b}}$ & $46.89^{c}$ & $45.20^{\mathrm{c}}$ \\
\hline $\mathrm{T}_{3}\left(\mu \mathrm{g} \cdot \mathrm{dL}^{-1}\right)$ & $0.28^{\mathrm{c}}$ & $0.25^{\mathrm{c}}$ & $0.49^{\mathrm{a}}$ & $0.39^{\mathrm{b}}$ \\
\hline $\mathrm{T}_{4}\left(\mu \mathrm{g} \cdot \mathrm{dL}^{-1}\right)$ & $9.31^{\mathrm{b}}$ & $9.31^{\mathrm{b}}$ & $11.52^{\mathrm{a}}$ & $10.97^{\mathrm{a}}$ \\
\hline
\end{tabular}

airT - air temperature; RH - relative humidity; RHL - radiante heat load; BGHI - black globe humidity index; Ws - Wind speed; pp month - precipitation for month; ST - surface temperature; RT - rectal temperature; RR - respiratory rate; $\mathrm{T}_{3}$ - triiodothyronine; $\mathrm{T}_{4}$ - thyroxine. Averages followed by the same letter in the row with the effect of the months. It does not differ statistically ( $\mathrm{p}>$ 0.05 ) by the Tukey test.

The month of June stands out for having higher RH values, due to higher rainfall (Table 2). Relative humidity is an important variable that directly influences heat exchange by evaporation. If the environment is saturated with water particles, heat loss can be hampered, so the animal finds it difficult to lose heat via respiratory evaporation; as a consequence, this may lead to an increase in its rectal temperature (Table 2). According to Maia et al. (2005) and Collier and Gebremedhin (2015), during the wetter months, there may be a reduction in the activation of evaporative mechanisms with consequent difficulties in the processes of cutaneous and respiratory thermolysis; this phenomenon was observed for the RR in June (54.68 breaths. $\min ^{-1}$ ) compared to during the month of March (64.91 breaths. $\left.\mathrm{min}^{-1}\right)$. In this way, the importance and adoption of adequate facilities in the flocks is reinforced, in order to improve the thermal sensation of the animals, even for the locally-adapted animals.
In September, in spite of observing higher RHL (671.89 $\left.\mathrm{wm}^{-2}\right)$ and BGHI (91.20) values, these variables were not responsible for triggering the studied thermoregulatory variables, with values significantly lower than those found in March and June, since in September, the airT was not the highest and the RH values were the lowest among the studied months. This behavior may facilitate heat exchange by evaporative means, probably skin evaporation in particular, which may be affected by air velocity, ambient temperature, relative humidity, and solar and thermal radiation. The velocity of the air (or wind) considerably increases heat loss by evaporation from the surface of the skin; as it penetrates into the skin, the hair acts as thermal insulation (MCARTHUR, 1987). As in September, the wind speed (Ws) was higher (Table 2); this may have influenced heat loss through skin evaporation in the studied animals. Hillman et al. (2001), in a study on the evaporative and convective cooling of cows in hot and humid 
environments, observed that increasing the air velocity on the hair surface from approximately $0.2 \mathrm{~m} . \mathrm{s}^{-1}$ to approximately $0.9 \mathrm{~m} . \mathrm{s}^{-1}$ increased evaporation rates $\left(\mathrm{m}^{2} . \mathrm{h}\right)-1$ for approximately $350 \mathrm{~g}$ $(\mathrm{m} 2 \times \mathrm{h})-1$, without an additional increase when the air velocity was increased to $2.2 \mathrm{~m} \cdot \mathrm{s}^{-1}$.

Although December had lower values of RHL (549.93 $\mathrm{wm}^{-2}$ ) and BGHI (85.02), possibly explained due to greater cloudiness associate with greater rainfall (Table 2$)$, the airT $\left(36.71{ }^{\circ} \mathrm{C}\right)$ was the highest of all the months in the study. As ST has a direct relation with airT, the body surface will absorb heat and heat will increase ST, however, there was no difference between the thermoregulatory variable values from the months of September and December and the lowest values for RR (Table 2).

During the months in which the animals used their physiological variables with greater intensity to maintain homeothermia, since they were exposed to a combination of more stressful environmental factors (March and June), the values of triiodothyronine ( $\mathrm{T}_{3}$ - 0.28 and $0.25 \mu \mathrm{g} . \mathrm{dL}^{-1}$, respectively) and thyroxine $\left(\mathrm{T}_{4}-9.31\right.$ and $9.31 \mu \mathrm{g} . \mathrm{dL}^{-1}$, respectively) were lower compared to during the months of September and December $\left(\mathrm{T}_{3}-0.49\right.$ and $0.39 \mu \mathrm{g} . \mathrm{dL}^{-1}, \mathrm{~T}_{4}-11.52$ and $10.97 \mu \mathrm{g} . \mathrm{dL}^{-1}$, respectively). Costa et al. (2015) and Leite et al. (2017), in studying the concentrations of $\mathrm{T}_{3}$ and $\mathrm{T}_{4}$ in the same breed, found that the secretions of thyroid hormones were higher when the environmental conditions were considered more comfortable. These results resemble those found by Starling et al. (2005), who worked with released animals.

$\mathrm{All}_{3}$ and $\mathrm{T}_{4}$ values in all months were above the values considered normal for the species; according to Dias et al. (2004), $\mathrm{T}_{3}$ can vary between 0.09 and $0.23 \mu \mathrm{g} \cdot \mathrm{dL}^{-1}$ and $\mathrm{T}_{4}$ between 3.8 and $7.7 \mu \mathrm{g} . \mathrm{dL}^{-1}$. These dosages can not be considered elevated, since one of the main consequences of hyperthyroidism is muscle weakness, due to circulatory insufficiency, requiring double oxygen and nutrients to maintain basal metabolic activity (DICKSON, 2006); these problems were not found in this study. A thyroid response was observed in the months in which there was a reduction in hormonal concentrations, during the months in which the animals more intensively activated their mechanisms in an attempt to maintain body temperature.

Johnson et al. (1988) emphasize that in warm environments, there is an increase in mean body temperature, followed by a reduction in thyroid activity. As such, $\mathrm{T}_{3}$ and $\mathrm{T}_{4}$ may have reduced levels in animals exposed to high temperatures, associated with a lower rate of heat production. The reduction in the $T_{3}$ and $T_{4}$ concentrations (Table 2) that occurred in this study may not equate to a decrease in metabolism since the values were not lower than the reference values for ovine species.

Façanha et al. (2010) mention that thyroid hormones can be considered a physiological parameter of environmental adaptation. The results of the present study state that the thyroid gland was not sensitive to the alteration of environmental conditions, demonstrating the importance of identifying genetic groups with proven thermolysis efficiency. Reductions below the normal levels of these hormone concentrations represent negative reflexes in important organic functions related to performance, since they act in synergy with other hormones, such as prolactin and growth hormone (FAÇANHA-MORAIS et al., 2008).

The semi-arid environment is characterized by high air temperature throughout the year. Excess solar radiation can cause changes to the coat characteristics of the animals, especially those that graze during the day, due to the system in which they are living. The highest values of coat thickness (CT) and hair density (NH) occurred in the months of September (at the spring equinox) and during the lowest RHL (December, summer solstice), respectively (Figure 2). Similar responses were found by Costa (2018) in Morada Nova sheep raised in semi-arid Paraibano, and Leite et al. (2017) in Morada Nova sheep raised in the Jaguaribe Valley-Ce. 
Figure 2. Mean of the annual behavior of the hair density $\left(\mathrm{NH} / \mathrm{cm}^{2}\right)$, hair diameter (HD), coat thickness (CT) and hair length (HL) of Morada Nova sheep in semiarid environment.
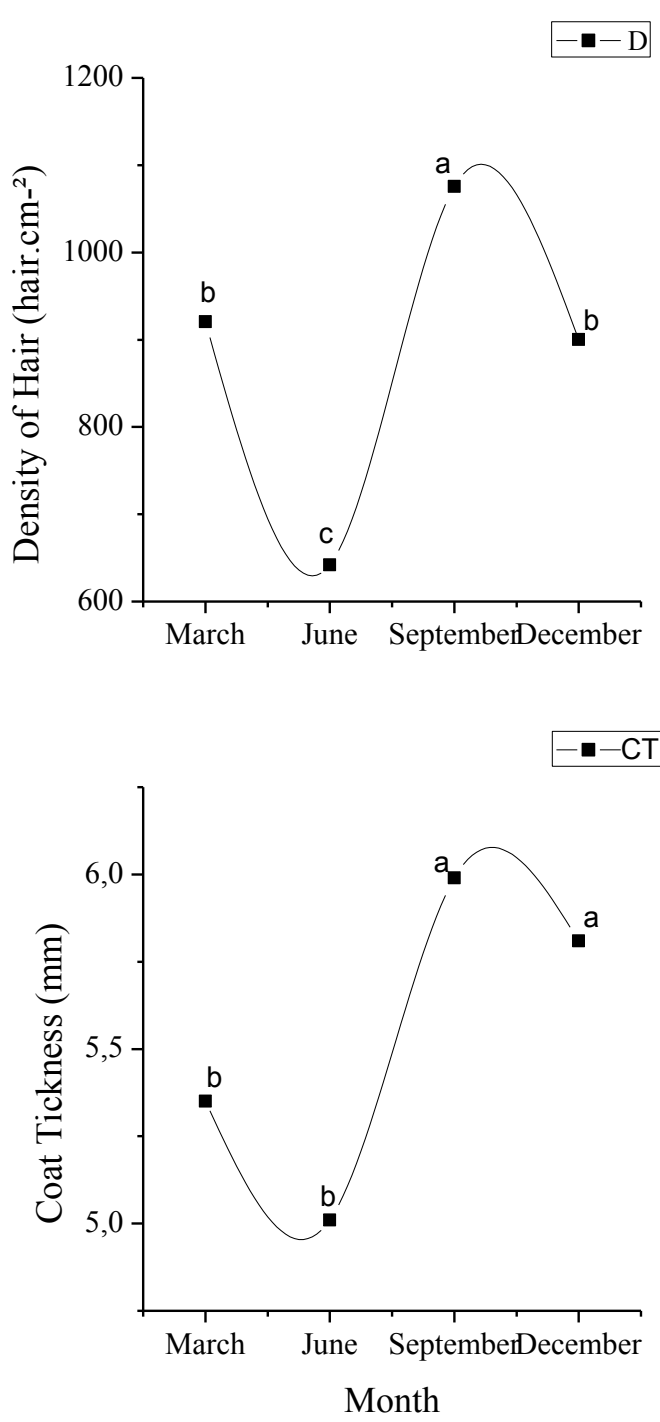

In the present study, there was a reduction in the NH mainly during periods with rainfall, in June and December (Figure 2 and Table 2); these results may be attributed to a possible change of hairs occurring in this period. These results are similar to those found by Costa (2018) in a study of animals of the same breed. According to Nixon et al. (2002), two hair changes occur in animals living in a temperate region: one in September and another in March. In the present study, this probably occurred in the months of June and December, as the animals were in a tropical region.
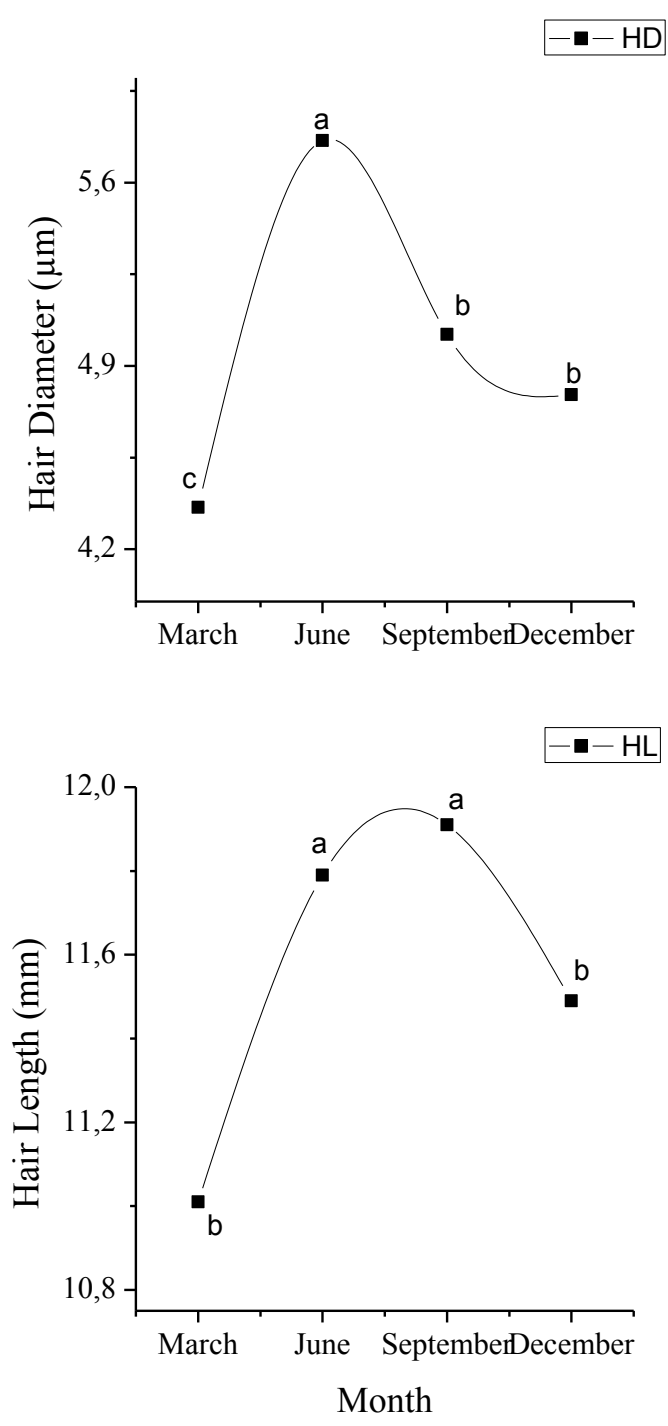

There were higher values of RHL and BGHI (Table 2) in the month of September. This means that there was a higher incidence of radiation and a higher Thermal Comfort Index for the animals exposed to this environment, in which the coat of the animals was more dense and thick, formed by longer hairs (Figure 2), which can provide protection of the corporeal surface against ultraviolet rays; this is very important for animals in a tropical region. According to Silva (2000), hair represents the border between the climatic environment and the animal's body, and can influence the thermal balance. The 
thermoregulatory role of the hair can be divided into two components: protection against excess solar radiation absorption and heat dissipation of the animal's surface. Thus, the physical characteristics of the animals in this specific month acted as a barrier that possibly decreased the absorption of the intense direct solar radiation, which promoted greater protection of the epidermis against the radiation of short waves, characteristics that make these animals adapted to grazing in the open.

Silva (1999) reports that having shorter, thicker and less numerous hair is advantageous for animals with pigmented epidermis; since these animals need to dissipate heat, these characteristics favor convective and evaporative thermolysis on the skin surface. The same above-mentioned coat characteristics were observed in the present work during the months in which the animals needed to more intensely activate the thermoregulatory mechanisms of heat dissipation (March and June), as a reaction to the combined action of the environmental variables being considered more stressful (Table 2 and Figure 2). This corroborates the idea that the coat characteristics assumes a fundamental importance for thermal exchange in order to influence the animal's thermal balance (BERTIPAGLIA et al., 2007; SILVA, 2008).

Differences in the hair variable values were very small throughout the year: a difference of $0.98 \mathrm{~mm}$ for CT, 433.1 hairs. $\mathrm{cm}^{-2}$ for NH, $1.1 \mathrm{~mm}$ for HL and $1.4 \mu \mathrm{m}$ for HD. Together, these characteristics help animals remain in a thermal balance throughout the year. This demonstrates that Morada Nova sheep have the coat characteristics of animals adapted to the studied environment, a positive point to enrich the information about this breed that both giving the breed adaptability to semi-arid environments. In general, the coat characteristics demonstrated their role in maintaining the thermal balance of the animals throughout the year (Figure 2), either in terms of protection against the excess absorption of solar radiation, characteristics observed in September, or in terms of helping with heat dissipation (March and June), because the morphological characteristics of the hair can be considered good indicators of adaptation (CENA; MONTEITH, 1975).

A multivariate approach describes a phenomenon at the global level and can improve understanding and help define the adaptive profile; this aids in the search for phenotypic markers of a population while considering all the variables simultaneously, allowing for consistent and useful interpretations (FERREIRA et al., 2009). The PCA showed that the variables that had the highest correlation explained the total variation in the use of the different thermoregulation mechanisms of the animals during the studied months (Figure 3). When evaluating axes 1 and 2, the month of March showed a greater influence of variables such as RT, RR, ST, CT, HL and $\mathrm{T}_{4}$, whereas in June, RR, RT, $\mathrm{ST}, \mathrm{NH} . \mathrm{cm}^{-2}, \mathrm{CT}$ and $\mathrm{T}_{4}$ had a greater influence, due to the environmental conditions that the animals were exposed to during the month. There was a similarity in the use of the characteristics during the above-mentiomned months since they comprise the rainy season and have similar environmental characteristics that are considered more stressful due to the combination of high $\mathrm{RH}$ and airT. In September, the highlighted variables were ST, CT, $\mathrm{HL}, \mathrm{NH} . \mathrm{cm}^{-2}$, possibly in response to high airT, RHL and BGHI, in order to use the coat characteristics as a form of physical protection. In December, there was a greater influence of variables such as $\mathrm{T}_{3}, \mathrm{~T}_{4}$, HL and HD. 
Figure 3. Principal components analysis for the environmental, physiological, morphological and thyroid hormone variables in the months studied. Measures were taken to: airT = air temperatura, $\mathrm{RH}=$ relative humidity, $\mathrm{RHL}=$ radiante heat load, BGHI - black globe humidity index, Ws $=$ Wind speed, ST = surface temperature, RT= rectal temperature, $\mathrm{RR}=$ respiratory rate, $\mathrm{NH} \cdot \mathrm{cm}^{-2}=$ hair density, $\mathrm{HD}=$ hair diameter, $\mathrm{CT}=$ coat tickness, $\mathrm{HL}=\mathrm{hair}$ length, $\mathrm{T}_{3}=$ triiodothyronine $\mathrm{e} \mathrm{T}_{4}=$ thyroxine.
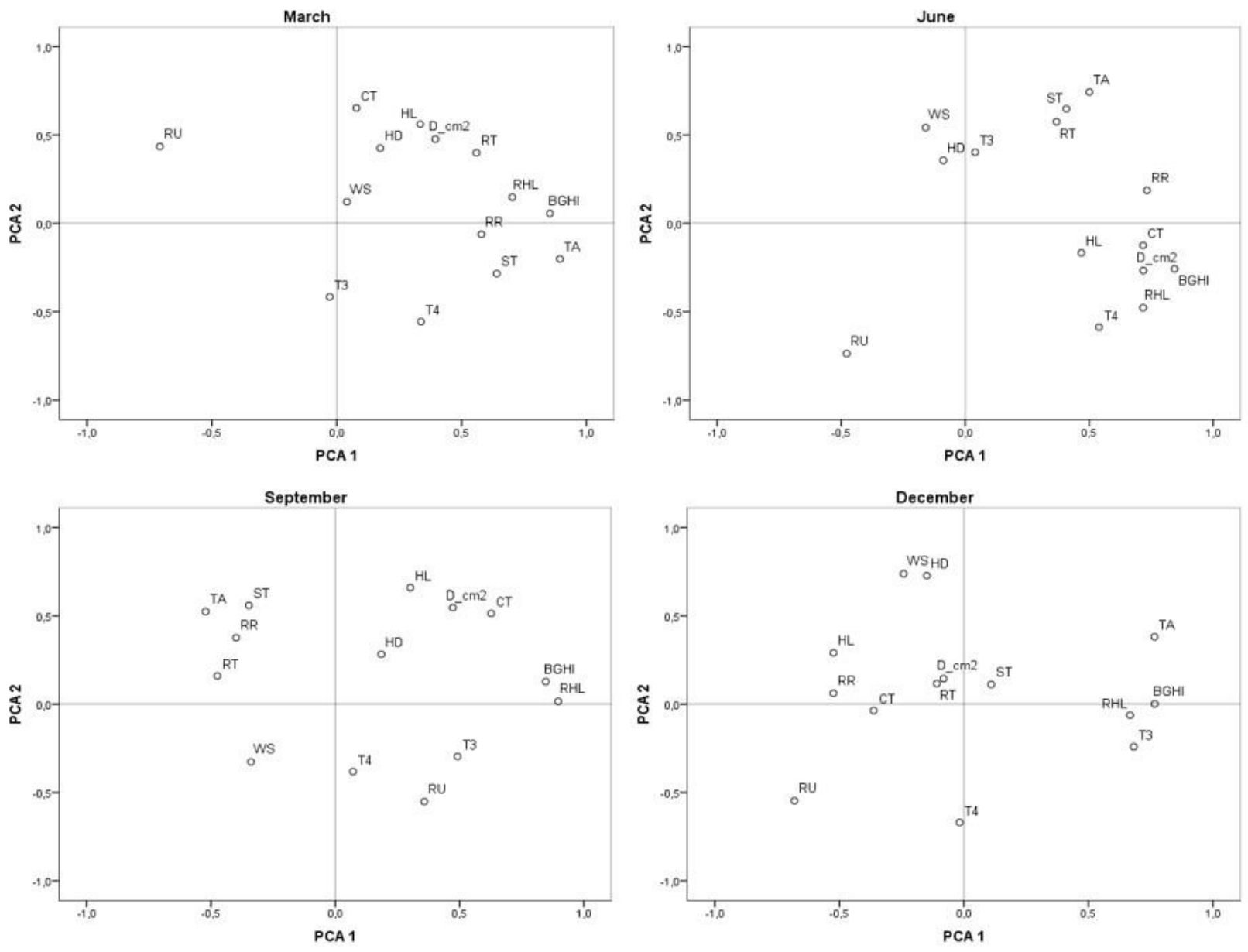

All airT averages were above $30^{\circ} \mathrm{C}$ throughout the experimental period in all evaluated flocks (Table 3). According to Baêta and Souza (1997), the thermal comfort range for sheep is between 20 and $30{ }^{\circ} \mathrm{C}$. Environmental conditions usually differ between flocks, so animal responses also differ in response to this environmental difference, even when they are located in the same city, since the specific location and characterization of each herd has its peculiarities.

The highest thermal amplitude between the flocks was observed in March with a $5.52{ }^{\circ} \mathrm{C}$ difference, registering a high average of 37.92

${ }^{\circ} \mathrm{C}$ in flock 1 and lower than $32.47{ }^{\circ} \mathrm{C}$ in flock 4 (Table 3). In response to the environmental variables, the animals from flock 1 were those that registered higher values of ST, RR and RT in order to thermoregulate, as a response to the combined action of factors related to the high values of airT, RHL and BGHI. The animals in flock 3, even with the lowest airT compared to flock 1, were forced to effectively increase the values of RT, RR and ST to thermoregulate due to the combination of high RH values, RHL and BGHI. However, flocks 2 and 4 did not differ statistically in relation to the use of RR, RT and ST, even though they differed 
statistically in terms of environmental variables. Flock 1 had a higher airT and flock 3 had a higher $\mathrm{RH}$; when combined with other environmental factors, these environmental conditions may have been determinants of the intensity of the use of thermoregulation mechanisms during the month of March (Table 3).

Table 3 Mean of environmental variables and thermoregulators of Morada Nova ewes with flock effect within the month collected.

\begin{tabular}{|c|c|c|c|c|c|c|c|c|c|}
\hline Month & Flock & $\begin{array}{l}\text { airT } \\
\left({ }^{\circ} \mathrm{C}\right)\end{array}$ & $\begin{array}{l}\text { RH } \\
(\%)\end{array}$ & $\begin{array}{c}\text { RHL } \\
\left(\mathrm{w} \cdot \mathrm{m}^{-2}\right)\end{array}$ & BGHI & $\begin{array}{c}\mathrm{Ws} \\
\left(\mathrm{m} \cdot \mathrm{s}^{-1}\right)\end{array}$ & $\begin{array}{l}\mathrm{ST} \\
\left({ }^{\circ} \mathrm{C}\right)\end{array}$ & $\begin{array}{l}\text { RR (brea- } \\
\text { th. } \text { min }^{-1} \text { ) }\end{array}$ & $\begin{array}{l}\mathrm{RT} \\
\left({ }^{\circ} \mathrm{C}\right)\end{array}$ \\
\hline \multirow{4}{*}{ March } & 1 & $37.92^{\mathrm{a}}$ & $33.94^{\mathrm{c}}$ & $670.36^{b}$ & $92.52^{\mathrm{a}}$ & $1.06^{b}$ & $38.71^{\mathrm{a}}$ & $89.51^{\mathrm{a}}$ & $39.39^{\mathrm{a}}$ \\
\hline & 2 & $36.93^{\mathrm{a}}$ & $40.63^{b}$ & $700.99^{a}$ & $94.08^{\mathrm{a}}$ & $1.56^{\mathrm{a}}$ & $36.18^{b}$ & $47.34^{\mathrm{c}}$ & $39.26^{\mathrm{a}}$ \\
\hline & 3 & $33.95^{b}$ & $45.25^{\mathrm{a}}$ & $665.44^{\mathrm{b}}$ & $90.09^{b}$ & $1.35^{\mathrm{ab}}$ & $36.50^{\mathrm{b}}$ & $67.75^{\mathrm{b}}$ & $38.81^{\mathrm{b}}$ \\
\hline & 4 & $32.47^{\mathrm{c}}$ & $42.13^{\mathrm{ab}}$ & $604.01^{\mathrm{c}}$ & $85.23^{\mathrm{c}}$ & $1.00^{\mathrm{b}}$ & $36.94^{b}$ & $53.21^{\mathrm{c}}$ & $38.47^{\mathrm{c}}$ \\
\hline \multirow{4}{*}{ June } & 1 & $33.09^{b}$ & $53.48^{\mathrm{a}}$ & $676.93^{b}$ & $90.66^{\mathrm{b}}$ & $0.74^{\mathrm{c}}$ & $34.22^{c}$ & $54.77^{\mathrm{b}}$ & $39.05^{\mathrm{b}}$ \\
\hline & 2 & $31.68^{\mathrm{c}}$ & $56.67^{\mathrm{a}}$ & $558.31^{\mathrm{c}}$ & $82.58^{\mathrm{d}}$ & $1.08^{b}$ & $34.06^{\mathrm{c}}$ & $33.28^{\mathrm{c}}$ & $38.67^{\mathrm{c}}$ \\
\hline & 3 & $33.09^{\mathrm{b}}$ & $51.94^{\mathrm{a}}$ & $726.34^{a}$ & $93.42^{\mathrm{a}}$ & $0.64^{\mathrm{c}}$ & $37.56^{\mathrm{b}}$ & $71.40^{\mathrm{a}}$ & $39.00^{\mathrm{b}}$ \\
\hline & 4 & $36.94^{\mathrm{a}}$ & $37.90^{\mathrm{b}}$ & $567.59^{\mathrm{c}}$ & $86.14^{\mathrm{c}}$ & $1.55^{\mathrm{a}}$ & $38.79^{\mathrm{a}}$ & $60.62^{\mathrm{b}}$ & $39.40^{\mathrm{a}}$ \\
\hline \multirow{4}{*}{ September } & 1 & $35.35^{\mathrm{b}}$ & $38.23^{b}$ & $659.04^{b}$ & $90.36^{b}$ & $1.56^{\mathrm{b}}$ & $35.92^{\mathrm{ab}}$ & $45.48^{b}$ & $38.86^{\mathrm{a}}$ \\
\hline & 2 & $34.28^{\mathrm{bc}}$ & $40.35^{\mathrm{ab}}$ & $806.71^{\mathrm{a}}$ & $98.13^{\mathrm{a}}$ & $1.02^{\mathrm{c}}$ & $34.66^{\mathrm{bc}}$ & $38.67^{\mathrm{bc}}$ & $38.39^{\mathrm{b}}$ \\
\hline & 3 & $38.11^{\mathrm{a}}$ & $33.72^{\mathrm{c}}$ & $598.34^{c}$ & $88.46^{\mathrm{b}}$ & $1.53^{b}$ & $36.73^{\mathrm{a}}$ & $61.32^{\mathrm{a}}$ & $38.91^{\mathrm{a}}$ \\
\hline & 4 & $33.63^{c}$ & $42.95^{\mathrm{a}}$ & $578.83^{c}$ & $84.72^{\mathrm{c}}$ & $2.15^{\mathrm{a}}$ & $33.85^{\mathrm{c}}$ & $37.14^{c}$ & $38.83^{\mathrm{a}}$ \\
\hline \multirow{4}{*}{ December } & 1 & $35.32^{\mathrm{b}}$ & $43.03^{\mathrm{a}}$ & $527.11^{\mathrm{b}}$ & $82.94^{c}$ & $1.48^{\mathrm{a}}$ & $36.32^{\mathrm{a}}$ & $59.50^{\mathrm{a}}$ & $38.87^{\mathrm{a}}$ \\
\hline & 2 & $35.34^{\mathrm{b}}$ & $44.27^{\mathrm{a}}$ & $569.38^{\mathrm{a}}$ & $85.45^{\mathrm{b}}$ & $0.36^{\mathrm{c}}$ & $36.65^{\mathrm{a}}$ & $50.84^{\mathrm{b}}$ & $38.89^{\mathrm{a}}$ \\
\hline & 3 & $38.16^{\mathrm{a}}$ & $38.38^{\mathrm{b}}$ & $525.71^{\mathrm{b}}$ & $84.63^{\mathrm{b}}$ & $1.05^{\mathrm{b}}$ & $35.68^{\mathrm{a}}$ & $36.33^{c}$ & $38.71^{\mathrm{a}}$ \\
\hline & 4 & $37.80^{\mathrm{a}}$ & $31.58^{c}$ & $589.29^{\mathrm{a}}$ & $87.50^{\mathrm{a}}$ & $1.02^{\mathrm{b}}$ & $36.78^{\mathrm{a}}$ & $35.22^{\mathrm{c}}$ & $38.81^{\mathrm{a}}$ \\
\hline
\end{tabular}

airT - air temperature; RH - relative humidity; RHL - radiante heat load; BGHI - black globe humidity index; Ws - Wind speed; ST - surface temperature; RR - respiratory rate; RT - rectal temperature. Means followed by the same letter in the column did not differ statistically $(\mathrm{p}>0.05)$ by the Tukey test.

The month of June was the month with the highest $\mathrm{RH}$, since it was one of the months with higher precipitation and lower airT (Table 2). In flock 3, higher thermoregulatory variable values were recorded to the detriment of the high $\mathrm{RH}, \mathrm{RHL}$ and BGHI, followed by flock 4, such that the high airT in the same herd may have caused greater heating on the surface of the animal and a greater need for increased RR, and possibly an increase of the RT; these were followed by flocks 1 and 2, respectively, in terms of the need to use thermoregulatory mechanisms to maintain homeothermia (Table 3).

In the month of September, the highest RHL and BGHI averages were recorded. However, flock 3 probably needed to increase the values of RT, RR and ST because of the combination of the high airT registered with the other environmental variables, leading to greater thermal discomfort for the animals, followed by flock 1 , which registered the second highest airT combined with high RHL and BGHI. Flock 2 was able to maintain low values of the studied physiological variables, even in relation to the highest RHL and BGHI averages, possibly due to the adaptive capacity and phenotypic plasticity of the Morada Nova breed (Table 3).

December showed the lowest average RHL and BGHI values, possibly due to the greater cloudiness observed in during this period, since there was 
rainfall (Table 2). Regarding the responses of the animals, RT and ST did not differ statistically across the four studied flocks. Flock 1 used RR more effectively compared to flock 2 , and there was no statistical difference between flocks 3 and 4; this was possibly affected by the highest $\mathrm{RH}$ recorded in flocks 1 and 2, compared to flocks 3 and 4, due to the difficulty of the dissipation of heat when in an environment with higher RH (Table 3).

The months of March and June are considered the rainy season, and it is important to note that during these months, some flocks showed higher values of RR [40-60 and 60-80 breaths.min ${ }^{-1}$, corresponding to low and moderate stress, respectively, according to Silanikove (2000)] and RT, probably due to the high $\mathrm{RH}$, associated with RHL, BGHI and airT, since these impede heat loss. All RT values (Table 3 ), independent of month and flock, remained within the normal values for the species up to 39.7 ${ }^{\circ} \mathrm{C}$ according to Roger (2008), demonstrating that changes in the organism were able to compensate for the environmental stress to which the animals were exposed. According to Gebremedhin et al. (2008), RT is considered the most reliable indicator for the evaluation of thermal stress.

The months of September and December are during the dry season, with a low $\mathrm{RH}$, which can facilitate the loss of heat through evaporation, even though rainfall was recorded in December (Tables 2 and 3 ). In the dry period, lower values of RT with a variation of $0.52{ }^{\circ} \mathrm{C}$ were observed, compared to the rainy season, varying by $0.92{ }^{\circ} \mathrm{C}$ (Table 3 ). Lower RR values were recorded (40-60 breaths. $\min ^{-1}$ ), demonstrating that the animals are under stress even with a high amount of thermal radiation, as demonstrated by the high RHL values. This heat was possibly dissipated with the aid of the hair characteristics and wind, since these are the months with the greatest wind in the region, and wind speed can contribute to the thermolysis of the animals (HILLMAN et al., 2001).

Of all the evaluated $\mathrm{T}_{3}$ concentrations, those that were within the species standards were only noted in flocks 2 and 3 during the months of March and June, and in flock 1 in December. The concentrations of $\mathrm{T}_{4}$ were only within the normal range in March in flock 3, in September in flock 2 and in December in flock 4; the remaining concentrations were all above the reference range (Table 4).

When analyzing thyroid hormone responses between the flocks, in March, the $\mathrm{T}_{3}$ and $\mathrm{T}_{4}$ concentrations of flocks $2\left(0.16\right.$ and $\left.9.05 \mu \mathrm{g} . \mathrm{dL}^{-1}\right)$, $3\left(0.22\right.$ and $\left.5.84 \mu \mathrm{g} \cdot \mathrm{dL}^{-1}\right)$ and $4(0.38$ and 11.03 $\mu$ g.dL ${ }^{-1}$; Table 4), were considered statistically smaller and statistically different than that of flock $1\left(0.36\right.$ and $\left.12.60 \mu \mathrm{g} . \mathrm{dL}^{-1}\right)$. There were no statistical differences between flocks 2 and 3, nor flocks 1 and 4 . These reductions in thyroid hormone concentrations can be attributed to the known effect of the warm environment (Table 3), since in flocks 2 and 3, the recorded values of RHL, BGHI and airT were considered high. This reduction in $\mathrm{T}_{3}$ secretion may help to decrease the production of endogenous heat in an attempt to adjust to hot environments, even outside the reference range. Façanha-Morais et al. (2008), Al-Haidary et al. (2012), Starling et al. (2005), Maurya et al. (2010) and Koluman and Daskiran (2011) also found significant reductions in thyroid hormones as a response to high air temperature.

As for the coat characteristics, there was no statistical difference for CT in the studied farms during the month of March (Table 4), but greater variation was observed in the mean values of $\mathrm{NH} . \mathrm{cm}^{-2}$. However, lower values of CT were followed by lower values of NH.cm ${ }^{-2}$. In flock 4, HL and HD may favor lower resistance to heat loss and higher transmission through the coat of hair; higher values were observed in flocks 1 and 3, with higher CT followed by NH.cm-2, HL and HD. This set of characteristics has a direct relationship with each other. These results reinforce the idea of adopting hair characteristics as indicators of adaptability, since the characteristics are possibly inherited together. 
Table 4. Means of thyroid hormones and hair morphological characteristics of Morada Nova ewes with flock effect within month collecting.

\begin{tabular}{|c|c|c|c|c|c|c|c|}
\hline Month & Flock & $\begin{array}{c}\mathrm{T}_{3} \\
\left(\mu \mathrm{g} . \mathrm{d} 1^{-1}\right)\end{array}$ & $\begin{array}{c}\mathrm{T}_{4} \\
\left(\mu \mathrm{g} \cdot \mathrm{dl}^{-1}\right)\end{array}$ & $\begin{array}{c}\mathrm{CT} \\
(\mathrm{mm})\end{array}$ & $\begin{array}{l}\text { NH.cm-2 } \\
\text { (hair.cm-2) }\end{array}$ & $\begin{array}{c}\mathrm{HL} \\
(\mathrm{mm})\end{array}$ & $\begin{array}{l}\mathrm{HD} \\
(\mu \mathrm{m})\end{array}$ \\
\hline \multirow{4}{*}{ March } & 1 & $0.36^{\mathrm{a}}$ & $12.60^{\mathrm{a}}$ & $5.22^{\mathrm{a}}$ & $1005.72^{\mathrm{a}}$ & $12.32^{\mathrm{a}}$ & $44.60^{\mathrm{ab}}$ \\
\hline & 2 & $0.16^{\mathrm{b}}$ & $9.05^{\mathrm{b}}$ & $5.40^{\mathrm{a}}$ & $878.75^{\mathrm{a}}$ & $9.50^{\mathrm{b}}$ & $41.63^{\mathrm{b}}$ \\
\hline & 3 & $0.22^{\mathrm{b}}$ & $5.84^{\mathrm{c}}$ & $5.54^{\mathrm{a}}$ & $1056.61^{\mathrm{a}}$ & $12.69^{\mathrm{a}}$ & $46.25^{\mathrm{a}}$ \\
\hline & 4 & $0.38^{\mathrm{a}}$ & $11.03^{\mathrm{a}}$ & $5.11^{\mathrm{a}}$ & $639.88^{b}$ & $8.85^{\mathrm{b}}$ & $41.13^{\mathrm{b}}$ \\
\hline \multirow{4}{*}{ June } & 1 & $0.34^{\mathrm{a}}$ & $8.06^{\mathrm{b}}$ & $5.23^{\mathrm{b}}$ & $437.50^{\mathrm{b}}$ & $12.65^{\mathrm{a}}$ & $52.04^{b}$ \\
\hline & 2 & $0.16^{\mathrm{b}}$ & $12.84^{\mathrm{a}}$ & $3.98^{c}$ & $397.28^{b}$ & $11.07^{\mathrm{b}}$ & $62.17^{\mathrm{a}}$ \\
\hline & 3 & $0.20^{\mathrm{b}}$ & $10.16^{\mathrm{a}}$ & $6.14^{\mathrm{a}}$ & $1176.75^{\mathrm{a}}$ & $12.32^{\mathrm{a}}$ & $54.22^{\mathrm{b}}$ \\
\hline & 4 & $0.35^{\mathrm{a}}$ & $8.10^{\mathrm{b}}$ & $4.48^{c}$ & $394.57^{b}$ & $11.00^{\mathrm{b}}$ & $63.33^{\mathrm{a}}$ \\
\hline \multirow{4}{*}{ September } & 1 & $0.48^{b}$ & $13.81^{\mathrm{a}}$ & $6.73^{a}$ & $1344.64^{\mathrm{a}}$ & $14.17^{\mathrm{a}}$ & $58.65^{\mathrm{a}}$ \\
\hline & 2 & $0.61^{\mathrm{a}}$ & $6.39 * b$ & $7.16^{\mathrm{a}}$ & $1368.37^{\mathrm{a}}$ & $11.60^{\mathrm{b}}$ & $48.15^{\mathrm{b}}$ \\
\hline & 3 & $0.31^{\mathrm{c}}$ & $11.52^{\mathrm{a}}$ & $5.69^{\mathrm{b}}$ & $924.11^{\mathrm{b}}$ & $11.32^{\mathrm{bc}}$ & $45.65^{\mathrm{b}}$ \\
\hline & 4 & $0.63^{\mathrm{a}}$ & $13.33^{\mathrm{a}}$ & $3.98^{c}$ & $573.43^{\mathrm{c}}$ & $10.40^{\mathrm{c}}$ & $50.42^{\mathrm{b}}$ \\
\hline \multirow{4}{*}{ December } & 1 & $0.20^{\mathrm{c}}$ & $12.11^{\mathrm{b}}$ & $6.10^{\mathrm{a}}$ & $905.95^{\mathrm{ab}}$ & $12.70^{\mathrm{a}}$ & $58.25^{\mathrm{a}}$ \\
\hline & 2 & $0.39^{\mathrm{ab}}$ & $9.32^{\mathrm{c}}$ & $6.07^{\mathrm{a}}$ & $816.13^{b}$ & $10.78^{\mathrm{bc}}$ & $35.55^{\mathrm{c}}$ \\
\hline & 3 & $0.34^{\mathrm{b}}$ & $14.73^{\mathrm{a}}$ & $5.47^{\mathrm{b}}$ & $999.01^{\mathrm{a}}$ & $12.02^{\mathrm{ab}}$ & $44.67^{\mathrm{b}}$ \\
\hline & 4 & $0.46^{\mathrm{a}}$ & $5.01^{\mathrm{d}}$ & $5.65^{\mathrm{ab}}$ & $858.86^{\mathrm{ab}}$ & $10.10^{\mathrm{c}}$ & $54.87^{\mathrm{a}}$ \\
\hline
\end{tabular}

$\mathrm{T}_{3}$ - triiodothyronine; $\mathrm{T}_{4}$ - thyroxine; $\mathrm{CT}$ - coat tickness; NH.cm² - hair density. $\mathrm{cm}^{-2} ; \mathrm{HL}$ - hair length; HD - hair diameter. Means followed by the same letter in the column did not differ statistically $(\mathrm{p}>0.05)$ by the Tukey test.

In June, flocks 2 and 3 had the lowest concentrations of $\mathrm{T}_{3}\left(0.16\right.$ and $0.20 \mu \mathrm{g} \cdot \mathrm{dL}^{-1}$, respectively) and were statistically different from flocks 1 and 4 (0.34 and $0.35 \mu \mathrm{g} . \mathrm{dL}^{-1}$, respectively), which had higher concentrations of $\mathrm{T}_{3}$; there was no statistical difference between flocks 2 and 3, as well as between flocks 1 and 4 (Table 4). However, $\mathrm{T}_{4}$ remained at higher concentrations in flocks $2\left(9.32 \mu \mathrm{g} . \mathrm{dL}^{-1}\right)$ and $3\left(14.73 \mu \mathrm{g} . \mathrm{dL}^{-1}\right)$, while $\mathrm{T}_{3}$ simulatenously showed lower concentrations (Table 4). It is known that $T_{4}$ has a great influence on the development of the mammary gland and the initiation of lactation, in addition to synergistic action with the growth hormone (RANDALL et al., 1997). This decrease of $\mathrm{T}_{3}$ allied with the maintenance of $\mathrm{T}_{4}$ secretion in the studied conditions may indicate a possible adaptive mechanism of Morada Nova sheep to maintain the values of the hormone responsible for growth and development and reduce only $\mathrm{T}_{3}$ that has greater energy production power, since $\mathrm{T}_{3}$ has a higher biological activity than $\mathrm{T}_{4}$ (BRTKO et al., 1994; FELDMAN; NELSON, 2004; MCNABB, 1995). The behavior of the coat characteristics observed in the previous month differed only in the animals' use of the flocks, since flock 2 had low values of CT, NH.cm-2 and HL, as well as flock 3, with higher CT followed by $\mathrm{NH} . \mathrm{cm}^{-2}$ and HL. For flock 2 , these results can be explained by the fact that, despite the low values of airT, RHL and BGHI, the RH was the highest of all the months studied in this flock in this specific month, and the animals from this flock had to decrease their heat production by reducing the concentration of $\mathrm{T}_{3}$, as well as by using the characteristics of the outer layer to lose heat. In flock 3, the presence of high RHL (726.34 $\mathrm{wm}^{-2}$ ) and BGHI (93.42), as presented in Table 3, may justify the decrease in $\mathrm{T} 3$ concentration (Table 4), and the higher mean coat characteristics may 
indicate the need for protection. Since RR and ST were also high, these animals could use all these physiological and morphological devices in order to try to maintain a normal internal temperature.

In the months of September and December, flocks 1 and 3 were those that registered the lowest averages of the plasma concentration of $\mathrm{T}_{3}$, whereas the average concentrations of $\mathrm{T}_{4}$ remained high; these results were similar to those found in June in flocks 2 and 3 (Table 4). This result emphasizes the importance of maintaining $\mathrm{T}_{4}$ concentrations, as this may indicate that there was no reduction in the activity of the hypothalamus-hypophysisthyroid axis, or any reduction of hypothalamic activity, which can be very beneficial for functions such as reproduction, lactation and growth. The coat characteristics followed the same pattern as in the previous months, since in September and December, flock 4 presented the lowest values of CT, NH. $\mathrm{cm}^{-2}$ and HL, and higher values of the same variables were noted in flock 2 in September and flock 1 in December.

Were noticed that the use of thermoregulatory mechanisms was very heterogeneous in the flocks, but upon a general analysis of the data (Tables 3 and 4), noting how the flocks used certain mechanisms, it was noted that flocks 1 and 3 had to use a greater number of characteristics in order to thermoregulate. This may possibly be due to the fact that farm 1, despite having housing for the animals, had a shortage of vegetation cover and trees on the property, which may justify the greater use of thermoregulatory mechanisms due to the microclimate that the trees can offer. Similarly, farm 3 did not have fixed masonry housing to better house the animals; they lived in pens with only native trees in the locations where they are collected at night, and the greater daytime (sun) and nighttime (wind) environmental exposure is reflected in specific physiological responses, since they are closely related to the environment to which the animals inhabit.

\section{Conclusions}

The rainy season was considered to be the most stressful for the animals, given that they used a more intense set of variables in order to thermoregulate and maintain homeothermia, which justifies the importance of supplying shelter, with the objective of reducing overheating even in the face of their great adaptive capacity, as already demonstrated in previous studies.

Changes in coat characteristics were observed during all months of the year, helping to cope with the environment by providing both physical protection and heat dissipation. Coat characteristics could be indicated as a thermotolerance phenotypic marker, with the potential to be used as selection criteria in breeding and conservation programs for resistant animals.

\section{Acknowledgements}

The authors acknowledge EMBRAPA Caprinos e Ovinos. Capes and the collaboration of the participating properties of the Genetic improvement nucleus of the Morada Nova breed.

\section{References}

AL-HAIDARY, A. A.; ALJUMAAH, R. S.; ALSHAIKH, M. A.; ABDOUN, K. A.; SAMARA, E. M.; OKAB, A. B.; ALFURAIJI, M. M. Thermoregulatory and physiological responses of Najdi sheep exposed to environmental heat load prevailing in Saudi Arabia. Pakistan Veterinary Journal, Faisalabd, v. 32, n. 4, p. 515-519, 2012.

BAÊTA, F. C.; SOUZA, C. F. Ambiência em edificações rurais: conforto animal. Viçosa, MG: UFV, 1997. 246 p.

BERTIPAGLIA, E. C. A.; SILVA, R. G.; CARDOSO, V.; MAIA, A. S. C. Estimativas de parâmetros genéticos e fenotípicos de características do pelame e de desempenho reprodutivo de vacas Holandesas em clima tropical. Revista Brasileira de Zootecnia, Viçosa, MG, v. 36, n. 9, p. 351-359, 2007. DOI: dx.doi.org/10.1590/S151635982007000200011 .

BRTKO, J.; PASCUAL, A.; ARANDA, A. 3.5.3'-Triiodothyronine nuclear receptors and their role 
in the thyroid hormone action. Endocrine Regulations, Bratislava, v. 28, n. 3, p. 107-115, 1994.

CENA, K.; MONTEITH, J. L. Transfer processes in animal coats. Radiative transfer. Proceedings of Royal Society of London, London, v. 188, n. 2, p. 377-393, 1975. DOI: doi.org/10.1098/rspb.1975.0026

COLLIER, R. J.; GEBREMEDHIN, K. G. Thermal biology of domestic animals. Annual Review of Animal Biosciences, California, v. 3, n. 2, p. 513-532, 2015. DOI: doi.org/10.1146/annurev-animal-022114-110659

COSTA, W. P.; FAÇANHA, D. A. E.; LEITE, J. H. G. M.; SILVA, R. C. B.; SOUZA, C. H.; CHAVES, D. F.; VASCONCELOS, A. M.; SOTO-BLANCO, B.; VALE, A. M.; PIMENTA-FILHO, E. C. Thermoregulatory responses and blood parameters of locally adapted ewes under natural weather conditions of Brazilian semiarid region. Semina: Ciências Agrárias, Londrina, v. 36, n. 6, p. 4589-4600, 2015. DOI: 10.5433/1679-0359.2015v36n6Supl2p4589

COSTA, W. P.; PIMENTA FILHO, E. C. P.; MORAISLEITE, J. H. G.; SILVA, W. S. T.; SILVA, W. E.; LIMA, F. H. S.; PEIXOTO-JÚNIOR, G. N. A.; FAÇANHA, D. A. E. Coat characteristics and physiological responses of locally adapted ewes in semiarid region of Brazil. Semina: Ciências Agrárias, Londrina, v. 39, n. 3, p. 1281-1293, 2018. DOI: 10.5433/1679-0359.2018v39n $3 \mathrm{p} 1281$

DIAS, M. I. R.; CARNEIRO, M. J. R.; AZEVEDO, J. M. T.; FERREIRA, A. J.; CABRITA, A. M. S. Parâmetros hematológicos de bioquímica sanguínea geral, eletrólitos plasmáticos e das hormonas relacionadas com a função da tiroide na ovelha da raça Churra da Terra Quente. Revista Portuguesa de Ciências Veterinárias, Lisboa, v. 99, n. 550, p. 99-107, 2004.

DICKSON, W. M. Endocrinologia. reprodução e lactação. In: SWENSON, M. J.; REECE, W. O. Dukes fisiologia dos animais domésticos. 12. ed. Rio de Janeiro: Guanabara Koogan S. A., 2006. p. 667-671.

FAÇANHA, D. A. E.; SILVA, R. G.; MAIA, A. S. C.; GUILHERMINO, M. M.; VASCONCELOS, A. M. Variação anual de características morfológicas e da temperatura de superfície do pelame de vacas da raça Holandesa em ambiente semiárido. Revista Brasileira de Zootecnia, Viçosa, MG, v. 39, n. 4, p. 837-844, 2010.

FAÇANHA-MORAIS, D. A. E.; MAIA, A. S. C.; SILVA, R. G.; VASCONCELOS, A. M.; LIMA, P. O.; GUILHERMINO, M. M. Variação anual de hormônios tireoidianos e características termorreguladoras de vacas leiteiras em ambiente quente. Revista Brasileira de
Zootecnia, Viçosa, MG, v. 37, n. 3, p. 538-545, 2008. DOI: dx.doi.org/10.1590/S1516-35982008000300020

FELDMAN, E, C.; NELSON, R. W. Canine and feline endocrinology and reproduction. $3^{\text {th }}$ ed. Philadelphia: Saunders, 2004. 1089 p.

FERREIRA,A. C. H.; NEIVA, J. N. M.; RODRIGUEZ, N. M.; CAMPOS, W. E.; BORGES, I. Avaliação nutricional do subproduto da agroindústria de abacaxi como aditivo de silagem de capim-elefante. Revista Brasileira de Zootecnia, Viçosa, MG, v. 38, n. 2, p. 223-229, 2009. DOI: dx.doi.org/10.1590/S1516-35982009000200002.

FERREIRA， J. B.; BEZERRA, A. C. D.; GUILHERMINO, M. M.; MORAIS-LEITE, J. H. G.; SILVA, W. E.; PAIAVA, R. D. M.; BARBOSA, T. N.; SOUZA, J. E. R.; FAÇANHA, D. A. E. Performance, endoparasitary control and blood values of ewes locally adapted in semiarid region. Comparative Immunology. Microbiology and Infectious Diseases, Lyon, v. 52, n. 1, p. 23-29, 2017. DOI: dx.doi.org/10.1016/j. cimid.2017.05.004

FERREIRA, J. B.; PAIVA, R. D. M.; BEZERRA, A. C. D.; SOUSA, J. E.; FAÇANHA, D.A.E. A multivariate approach to the diagnosis of gastrointestinal infection in ewes. Veterinary Parasitology, Amsterdam, v. 252, p. 95 97, 2018. DOI: doi.org/10.1016/j.vetpar.2018.02.015

GEBREMEDHIN, K. G.; HILLMAN, P. E.; LEE, C. N.; COLLIER, R. J.; WILLARD, S. T.; ARTHINGTON, J. D.; BROWN-BRANDL, T. M. Sweating rates of dairy cows and beef heifers in hot conditions. Transaction of the ASABE, St. Joseph, v. 51, n. 6, p. 2167-2178, 2008.

HILLMAN, P. E.; GEBREMEDHIN, K. G.; PARKHURST, A.; FUQUAY, J.; WILLARD, S. T. Evaporative and convective cooling of cows in a hot and humid environment. American Society of Agricultural and Biological Enginners, St. Joseph, v. 1, n. 1, p. 343350, 2001. DOI: $10.13031 / 2013.24114$

HOFFMANN, I. Climate changes and the characterization, breeding and conservation of genetic animal resources. Animal Genetics, Malden, v. 41, n. 1, p. 32-46, 2010. DOI: $10.1111 / \mathrm{j} .1365-2052.2010 .02043 . \mathrm{x}$

JOHNSON, H. D.; KATTI, P. S.; HAHN, L.; SHANKLIN, M. D. Short-term heat acclimation effects on hormonal profile of lactating cows. Missouri: Agri. Exp. Sta, p. 1-30, 1988. RESEARCH BULLETIN 1061.

KOLUMAN, N.; DASKIRAN, I. Effects of ventilation of the sheep house on heat stress growth and thyroid hormones of lambs. Tropical Animal Health and Production, Roslin, v. 43, n. 6, p. 1123-1127, 2011. DOI: 10.1007/s11250-011-9811-7 
LEE, D. H. K. Manual of field studies on heat tolerance of domestic animals. Roma: FAO, 1953. $161 \mathrm{p}$.

LEITE, J. H. G. M.; FAÇANHA, D. A. E.; COSTA, W. P.; CHAVES, D. F.; GUILHERMINO, M. M.; SILVA, W. S. T.; BERMEJO, L. A. Thermoregulatory responses related to coat traits of Brazilian native ewes: an adaptive approach. Journal of Applied Animal Research, Grange, Irlanda, v. 45, p. 1-7, 2017. DOI: 10.1080/09712119.2017.1302877

LEITE, J. H. G. M.; SILVA, R. G.; SILVA, W.S.T.; SILVA, W.E.;PAIVA, R.D.M.;SOUSA, J.E.R.;ASENSIO, L.A.B.; FAÇANHA, D.A.E. Locally adapted Brazilian ewes with different colors maintain homeothermy during the year in a equatorial semiarid environment. Internationa Journal Biometeorology, Kent, v. 62, n. 9, p. 1635-1644, 2018. DOI:10.1007/s00484-018-1563-x

MAIA, A. S. C.; SILVA, R. G.; BATTISTON LOUREIRO, C. M. Sensible and latent heat loss from body surface of Holstein cows in a Tropical environment. International Journal of Biometeorology, Kent, v. 50, n. 1, p. 17-22, 2005. DOI: 10.1007/s00484-005-0267-1

MAIA, A. S. C.; SILVA, R. G.; BERTIPAGLIA, E. C. A. Características do pelame de vacas Holandesas em ambiente tropical: um estudo genético e adaptativo. Revista Brasileira de Zootecnia, Viçosa, MG, v. 32, n. 4, p. 843-853, 2003. DOI: dx.doi.org/10.1590/S151635982003000400009 .

MARAI, I. F. M.; EL-DARAWANY, A. A.; FADIEL, A.; ABDEL-HAFEZ, M. A. M. Physiological traits as affected by heat stress in sheep - a review. Small Ruminant Research, Amsterdam, v. 71, n. 1, p. 1-12, 2007. DOI: doi.org/10.1016/j.smallrumres.2006.10.003

MAURYA, V. P.; SEJIAN, V.; KUMAR, D.; NAQVI, S. M. K. Effect of induced body condition score diferences on sexual behavior, scrotal measurements, semen attributes and endocrine responses in Malpura rams under hot semi-arid environment. Journal of Animal Physiology and Animal Nutrition, Berlin, v. 94, n. 3, p. 308-317, 2010. DOI: 10.1111/j.1439-0396.2010.01012.x.

MCARTHUR, A. J. Thermal interaction between animal and microclimate: a comprehensive model. Journal Theoretica Biology. Ann Arbor, Michigan, v. 126. n. 2, p. 203-238, 1987. DOI: doi.org/10.1016/S00225193(87)80229-1

MCDONALD, L. E. Veterinary endocrinology and reproduction. $3^{\text {th }}$ ed. Philadelphia: Lea \& Febiger, 1980. $560 \mathrm{p}$.

MCMANUS, C.; PALUDO, G. R.; LOUVANDINI, H.; GUGEL, R.; SASAKI, L. C. B.; PAIVA, S. R. Heat tolerance in Brazilian sheep: physiological and blood parameters. Tropical and Animal Health Production, Roslin, v. 41. n. 1, p. 95-101, 2009. DOI: 10.1007/ s11250-008-9162-1

MCNABB, F. M. Thyroid hormones. their activation. degradation and effects on metabolism. The Journal of Nutrition, Philadelphia, v. 125. n. 6, p. 1773-1776, 1995. DOI: 10.1093/jn/125.suppl_6.1773S

NIXON, A. J.; FORD, C. A.; WILDERMOTH, J. E.; CRAVEN, A. J.; ASHBY, M. G.; PEARSON, A. J. Regulation of prolactin receptor expression in ovine skin in relation to circulating prolactin and wool follicle growth status. Journal of Endocrinology, Melbourne, v. 172 , n. 3, p. 605-614, 2002. DOI: 0022-0795/02/0172605

PANAGAKIS, P. Black-globe temperature effect on short-term heat stress of dairy ewes housed under hot weather conditions. Small Ruminant Research, Amsterdam, v. 100, n. 1, p. 96-99, 2011. DOI: 10.1016/j. smallrumres.2011.06.006

RANDALL, D.; BURGREEN, W.; FRENCH, K. Animal physiology: mechanisms and adaptations. $4^{\text {th }}$ ed. New York: H. W. Freeman and Company, 1997. 727 p.

ROGER, P. A. The impact of disease and disease prevention on sheep welfare. Small Ruminant Research, Amsterdam, v. 76, n. 1, p. 104-111, 2008. DOI: doi. org/10.1016/j.smallrumres.2007.12.005

RUST, J. M.; RUST, T. Climate change and livestock production: A review with emphasis on Africa. South African Journal Animal Science, Cape Town, v. 43, n. 3, p. 254-267, 2013. DOI: dx.doi.org/10.4314/sajas.v43i3.3

SEJIAN, V.; MAURYA, V. P.; NAQVI, S. M. K. Adaptability and growth of Malpura ewes subjected to thermal and nutritional stress. Tropical and Animal Health Production, Roslin, v. 42, n. 8, p. 1763-1770, 2010. DOI: $10.1007 / \mathrm{s} 11250-010-9633-\mathrm{z}$

SILANIKOVE, N. Effects of heat stress on the welfare of extensively managed domestic ruminants. Livestock Production Science, New York, v. 67, n. 1-2, p. 1-18, 2000. DOI: doi.org/10.1016/S0301-6226(00)00162-7

SILVA, R. G. Biofisica ambiental: os animais e seu ambiente. São Paulo: FUNEP, 2008. 386 p.

SILVA, R. G. Estimativa do balanço térmico por radiação em vacas Holandesas expostas ao sol e à sombra em ambiente tropical. Revista Brasileira de Zootecnia, Viçosa, MG, v. 28, n. 6. p. 1403-1411, 1999. DOI: dx.doi. org/10.1590/S1516-35981999000600031

SILVA, R. G. Introdução à bioclimatologia animal. São Paulo: Nobel, 2000. 415 p. 
SILVA, R. G.; STARLING, J. M. C. Evaporação cutânea e respiratória em ovinos sob altas temperaturas ambientes. Revista Brasileira de Zootecnia, Viçosa, MG, v. 32, n. 6, p. 1956-1961, 2003. DOI: dx.doi.org/10.1590/S151635982003000800020

SILVA, W. E.; MORAIS-LEITE, J. H. G.; SOUSA, J. E. R.; COSTA, W. P.; SILVA, W. S. T.; GUILHERMINO, M. M.; ASENSIO, L. A. B.; FAÇANHA, D. A. E. Daily rhythmicity of the thermoregulatory responses of locally adapted Brazilian sheep in a semiarid environment. Internacional Journal Biometeorology, Kent, v. 61, n. 7, p. 1221-1231, 2017. DOI: 10.1007/s00484-016-1300-2

STARLING, J. M. C.; SILVA, R. G.; NEGRAO, J. A.; MAIA, A. S. C.; BUENO, A. R. Variação estacional dos hormônios tireoidianos e do cortisol em ovinos em ambiente tropical. Revista Brasileira de Zootecnia, Viçosa, MG, v. 34, n. 6, p. 2064-2073, 2005. DOI: org/10.1590/S1516-35982005000600032

UDO, H. M. Hair coat characteristics in Friesian heifers in the Netherlands and Kenya. Wagneingen: Meded. Landbouwhogeschool Wagneingen, 1978. 135 p.

VERÍSSIMO, C. J.; TITTO, C. G.; KATIKI, L. M.; BUENO, M. S.; CUNHA, E. A.; MOURAO, G. B.; OTSUK, I. P.; PEREIRA, A. M. F.; NOGUEIRA FILHO, J. C. M.; TITTO, E. A. L. Tolerância ao calor em ovelhas Santa Ines de pelagem clara e escura. Revista Brasileira de Saúde e Produção Animal, Salvador, v. 10, n. 1, p. 159-167, 2009. 